\title{
SEMIOTIK DALAM NOVEL 3 WALI 1 BIDADARI KARYA TAUFIQURRAHMAN AL-AZIZY
}

\author{
Andi Widiono ${ }^{1^{*}}$ \\ Dosen AMIK Dian Cipta Cendikia (DCC) Pringsewu Lampung \\ Pos-el: andiwidiono@gmail.com
}

\begin{abstract}
Abstrak
Sastra sebagai hasil karya seni manusia yang mempersoalkan masalah-masalah manusia dan sebagai wadah bagi sastrawan untuk menyampaikan ide tentang kehidupan manusia. Novel sebagai salah satu jenis sastra dapat diartikan sebagai sebuah karya sastra yang melukiskan kehidupan manusia baik perbuatan lahir maupun batinnya, sehingga terlahir suatu konflik yang disampaikan melalui struktur tanda-tanda atau semiotik yang mempunyai makna dan arti. Semiotik adalah ilmu tentang tanda yang ada dalam karya sastra. Kajian ini membahas bagaimanakah semiotik dalam novel 3 Wali 1 Bidadari karya Taufiqurrahman Al-Azizy. Adapun tujuan penelitian ini untuk mengetahui penggunaan tanda atau semiotik dalam novel 3 Wali 1 Bidadari karya Taufiqurrahman Al-Azizy. Dalam novel ditemukan banyak tanda atau semiotik yang memberikan manfaat bagi pembaca dan penikmat sastra. Karya sastra dengan keutuhannya secara semiotik dapat dipandang sebagai sebuah tanda. Pada penelitian ini penulis menggunakan metode deskriptif analisis. Metode deskriptif analisis dilakukan dengan cara mendeskripsikan fakta-fakta yang kemudian disusul dengan analisis. Berdasarkan analisis data pada novel 3 Wali 1 Bidadari karya Taufiqurrahman Al-Azizy disimpulkan mengandung tanda-tanda atau semiotik. Semua tanda-tanda tersebut dapat menambah wawasan kita dalam membaca dan menganalisis sebuah karya sastra khususnya novel, sehingga kita dapat mengartikan sebuah makna-makna yang terdapat pada sebuah novel secara jelas.
\end{abstract}

Kata Kunci: semiotik, ikon, indeks, dan simbol.

\section{PENDAHULUAN}

Sastra merupakan pengalaman hidup manusia, baik dari aspek manusia yang memanfaatkan bagi pengalaman hidupnya maupun dari aspek penciptanya, yang mengekspresikan pengalaman batinnya ke dalam karya sastra. Menurut Wellek dan Warren (2010: 3) sastra adalah suatu kegiatan kreatif dan sebuah karya seni. Selanjutnya, menurut Semi (2011: 8) sastra adalah suatu bentuk dan hasil pekerjaan seni kreatif yang objeknya adalah manusia dan kehidupannya dengan menggunakan bahasa sebagai mediumnya. Adapun bentuk karya sastra meliputi novel, cerpen, drama, dan puisi, yang di dalamnya terdapat cerita, ide, pesan atau gagasan baik secara tersirat maupun tersurat dengan menggunakan tanda atau semiotik sebagai alat penyampai pesan tersebut baik secara lisan maupun tertulis.

Pada umumnya dalam sebuah karya sastra, para pengarang dalam menyampaikan isi ceritanya baik tokohnya, temanya, latar, gaya bahasa, dan amanatnya banyak sekali terdapat ikon, indeks, dan simbol yang sulit dimengerti oleh pembaca. Ikon, indeks, dan simbol dalam karya sastra khususnya novel banyak mempunyai makna yang menggambarkan maksud dan pesan dari pengarang. Di dalam sebuah karya sastra khususnya novel banyak tanda atau semiotik yang memberikan manfaat bagi pembaca dan penikmat sastra. Karya sastra dengan keutuhannya secara semiotik dapat dipandang sebagai sebuah tanda. Sebagai suatu bentuk, karya sastra secara tulis khususnya novel mengandung tanda-menanda yang menyiratkan makna semiotik.

Kata novel berasal dari kata Latin novellus yang diturunkan pula dari kata noveis yang artinya "baru". Dikatakan baru karena jika dibandingkan dengan jenis-jenis sastra lainnya seperti puisi, drama, dan lain-lain, maka novel ini muncul kemudian (Tarigan, 2011: 167). Menurut Sudjiman (2010: 53) novel merupakan proses rekaan yang panjang yang menyuguhkan tokoh-tokoh dan menampilkan serangkaian peristiwa dan latar secara tesusun.

Semiotik merupakan ilmu tentang tanda-tanda. IImu ini menganggap bahwa fenomena sosial atau masyarakat dan kebudayaan itu merupakan tanda-tanda. Menurut Endraswara (2010: 64) semiotik 

sebuah objek representatif. Selanjutnya, Teeuw dalam (Rokhmansyah, 2014: 94) semiotik adalah tanda sebagai tindak komunikasi dan kemudian disempurnakannya menjadi model sastra yang mempertanggungjawabkan semua faktor dan aspek hakiki untuk pemahaman gejala susastra sebagai alat komunikasi yang khas di dalam masyarakat mana pun.

Jenis-jenis tanda menurut Peirce (dalam Endraswara, 2010: 65) yang utama ialah ikon, indeks, dan simbol. Ikon, yaitu tanda yang secara inheren memiliki kesamaan dengan arti yang ditunjuk. Misalnya, foto dengan orang difoto atau peta dengan wilayah geografisnya. Indeks, yaitu tanda yang mengandung hubungan kausal dengan apa yang ditandakan. Misalnya, asap menandakan adanya api, mendung akan menandakan akan turun hujan. Simbol, yaitu tanda yang memilki hubungan makna dengan dengan yang ditandakan bersifat arbriter, sesuai dengan konvensi suatu lingkungan sosial tertentu. Misalnya, bendera putih sebagai simbol ada kematian, ibu artinya ditentukan oleh konvensi masyarakat bahasa Indonesia.

Jenis karya sastra seperti novel merupakan salah satu bentuk karya sastra yang banyak di dalamnya terdapat tanda semiotik, karena dalam sebuah novel banyak terdapat tanda-tanda yang mempunyai makna, sehingga sebelum pembaca mengetahui pesan dari sebuah novel, pembaca perlu mencari maksud dari novel tersebut. Untuk itu menganalisis tanda semiotik pada sebuah novel sangatlah penting agar pembaca mendapatkan pesan dari pengarang secara tepat. Dalam menganalisis sebuah semiotik pada novel, seorang peneliti harus menganalisis sistem tanda itu dan menentukan konvensi-konvensi apa yang memungkinkan tanda-tanda atau struktur tanda-tanda dalam rangka sastra itu mempunyai makna. Unsur ini yang menjadikan penelitian semiotik karya sastra lebih optimal.

Salah satu novel yang menarik untuk diteliti dan di dalamnya banyak terdapat tanda atau semiotik yang mempunyai makna adalah novel 3 Wali 1 Bidadari karya Taufiqurrahman Al-Azizy. Tanda-tanda tersebut dapat ditemukan melalui unsur intrinsik yaitu tokoh, tema, latar, gaya bahasa, dan amanat yang tidak digambarkan secara jelas atau tersirat (implisit), sehingga menimbulkan banyak tanda-tanda yang mempunyai makna dan sangat bagus untuk diteliti. Elemen-elemen itu merupakan satuan-satuan tanda yang harus dianalisis secara sendiri-sindiri (dalam arti dieksplisitkan).

Novel 3 Wali 1 Bidadari karya Taufiqurrahman Al-Azizy menceritakan tentang seorang gadis yang cantik seperti bidadari anak dari seorang Kiai yang bernama Asma Putri Fadhila. Kecantikannya sungguh luar biasa dan Asma Putri Fadila sangat pandai dalam ilmu dunia maupun akhirat yang diperoleh melalui sebuah pesantren ketika di SMP dan SMA. Setiap lelaki yang melihat Asma tentunya akan jatuh cinta dan terpikat dengan kecantikannya dan keanggunannya. Banyak pria yang berusaha untuk mencuri hati Asma dan ingin menjadikannya sebagai istri. Akan tetapi, Asma berkeinginan untuk tidak menikah karena ia ingin semata-mata beribadah dan mengabdikan diri diri kepada Allah. Namun, akhirnya ia berubah pikiran karena mendapat petuah dari Kiai Faqih sehingga hatinya terketuk untuk menikah. Kemudian ia meminta kepada abahnya untuk dicarikan calon suami yang cocok untuk dirinya. Selanjutnya Kiai Faqih menyarankan Asma untuk menikah dengan Bilal atau Arsyad. Mereka merupakan alumni sebuah pondok pesantren Benda Kerep. Keduanya merupakan lelaki yang baik akhlaknya, taat beribadah, dan memilki wawasan agama yang luas. Novel 3 Wali 1 Bidadari karya Taufiqurrahman Al-Azizy ini merupakan sebuah kisah perjalanan mencari pasangan hidup, tetapi juga perjalanan memahami hakikat cinta sebagai karunia yang suci dari Allah. Novel ini menceritakan perjalanan hidup seorang wanita untuk menemukan pasangan hidupnya yang jalan ceritanya sangat berbeda dengan orang lain.

\section{METODE PENELITIAN}

Menurut Depdiknas (2010: 30) definisi konsep adalah satuan arti yang mewakili sejumlah objek yang mempunyai ciri yang sama. Definisi konsep yang penulis teliti dalam penelitian ini adalah semiotik dalam novel 3 Wali 1 Bidadari karya Taufiqurrahman Al-Azizy. Teknik pengumpulan data yang penulis gunakan dalam penelitian ini teknik studi pustaka, yaitu membaca dan mempelajari secara keseluruhan novel 3 Wali 1 Bidadari karya Taufiqurrahman Al-Azizy, kemudian mencari semiotik yang terdapat dalam novel tersebut. Setelah data terkumpul, maka diadakan analisis data. Dalam menganalisis data, penulis menggunakan metode deskriptif analisis. Metode deskriptif analisis adalah suatu metode yang mendeskripsikan fakta-fakta yang ada kemudian disusul dengan cara menganalisis (Ratna, 2010: 53).

Dengan metode deskriptif analisis ini, novel yang dijadikan objek penelitian semiotik yang meliputi: ikon, indeks, dan simbol, kemudian dianalisis dan diberi penjelasan dalam novel 3 Wali 1 Bidadari karya Taufiqurrahman Al-Azizy. Analisis dalam penelitian ini dilakukan secara deskriptif dengan langkah-langkah analisis data dalam penelitian ini sebagai berikut. 
SEMIOTIK DALAM NOVEL 3 WALI $1 \ldots \mid$... 55

1. Membaca dan mempelajari berbagai teori yang ada kaitannya dengan analisis novel.

2. Melakukan pembacaan semiotik yang meliputi pembacaan heuristik dan hermeneutik. Pembacaan heuristik adalah pembacaan berdasarkan struktur kebahasaannya atau secara semiotik adalah berdasarkan konvensi sistem semiotik tingkat pertama. Pembacaan hermeneutik adalah pembacaan ulang sesudah pembacaan heuristik dengan memberikan tafsiran berdasarkan konvensi sastranya.

3. Membuat sinopsis novel 3 Wali 1 Bidadari karya Taufiqurrahman Al-Azizy.

4. Menganalisis penggunaan tanda semiotik menurut Peirce yang meliputi ikon, indeks, dan simbol.

5. Menarik simpulan dari hasil analisis data pada novel 3 Wali 1 Bidadari karya Taufiqurrahman Al-Azizy.

\section{HASIL DAN PEMBAHASAN}

Sastra adalah karya dan kegiatan seni yang berhubungan dengan ekspresi dan kejiwaan yang berupa pengalaman dan imajinasi pengarang. Dengan membaca karya sastra kita dapat mengetahui berbagai jenis tanda atau semiotik yang dapat menambah pengetahuan bagi kita. Salah satu hal yang dapat kita pelajari pada novel 3 Wali 1 Bidadari karya Taufiqurrahman Al-Azizy yaitu tentang tanda atau semiotik, karena di dalam novel ini banyak sekali jenis-jenis tanda menurut teori Pierce yaitu ikon, indeks, dan simbol. Adapun hasil dan pembahasan semiotik pada novel 3 Wali 1 Bidadari karya Taufiqurrahman Al-Azizy tersebut akan diuraikan sebagai berikut.

\section{Ikon}

Ikon adalah tanda yang paling mudah dipahami karena kemiripannya dengan sesuatu yang diwakili. Oleh karena itu, ikon sering juga disebut gambar dari wujud yang diwakilinya. Kutipan novel 3 Wali 1 Bidadari karya Taufiqurrahman Al-Azizy yang menunjukkan adanya ikon terdapat pada kutipankutipan berikut.

Ketika itu, Cirebon masih bersahabat. Lengkung cakrawala masih indah dipandang mata. Angin pantai yang panas menjadi sendu ketika memeluk pohon-pohon dan mengipasi dedaunan. Jalan-jalan masih tampak asri dan bersih. Aspal tampak licin dan tak berlubang-lubang. Alun-alun masih dikelilingi pohon-pohon yang rindang dan teduh, dan burung-burung pun bertengger mesra di ranting-rantingnya.

(Taufiqurrahman Al-Azizy, 2013: 25)

Dari kutipan di atas, yang menunjukkan ikon adalah 'pohon'. Gambar pohon menandai pohon. Secara heuristik pohon mempunyai makna sebuah tanaman hidup. Secara hermeneutik mempunyai sebuah makna bahwa kota Cirebon sangat sejuk, damai, dan penduduknya yang sangat religius dan agamis.

Anak-anak kecil meminta Nyai Syarifah mengajari al-Qur'an sedang para pemuda dan pemudi meminta Kiai Baedlowi mengenalkan dan mengajarkan kitab-kitab kuning. Halaman rumah yang luas selalu ramai dengan kehadiran anak-anak ketika sore. Dan, ruang tamu yang cukup besar itu sanggup menampung para pemuda dan pemudi membaca al-Qur'an dan mengaji kitab-kitab kuning pada kiai.

(Taufiqurrahman Al-Azizy, 2013: 27)

Dari kutipan di atas, yang menunjukkan ikon adalah 'rumah'. Gambar rumah menandai rumah. Secara heuristik rumah mempunyai makna tempat tinggal manusia. Secara hermeneutik mempunyai makna rumah Kiai Baedlowi sebuah rumah yang memberikan kesejukan dan kenyamanan bagi siapa yang datang baik anak-anak kecil, para pemuda, maupun orang tua.

Sungguh, bukan hanya dari kalangan yang terdidik dan terpelajar serta haus ilmu saja yang menghormati Kiai Baedlowi. Bahkan, sesama pedagang, pemilik toko-toko bangunan, toko-toko kelontong, penjual jamu gendong, sopir angkot, tukang ojek, sampai tukang bangunan pun menghormatinya. 
Dari kutipan di atas, yang menunjukkan ikon adalah 'toko-toko'. Gambar toko menandai toko. Secara heuristik toko mempunyai makna tempat menjual barang-barang. Secara hermeneutik mempunyai makna semua para pemilik toko yang dekat dengan tempat Kiai Baedlowi berdagang sangat menghormatinya.

Kiai Baedlowi tersenyum.Bawuk waspada. Berkata Kiai Baedlowi, "Mas bisa mengambil isinya, tetapi tolong KTP saya dan istri dikembalikan.

(Taufiqurrahman Al-Azizy, 2013: 33)

Dari kutipan di atas, yang menunjukkan ikon adalah 'KTP'.. Secara heuristik mempunyai makna kartu identitas seseorang. Secara hermeneutik mempunyai makna KTP bagi Kiai Baedlowi dan Nyai Syarifah sangat berharga dan penting.

Majelis-majelis di Jakarta pun sering kali mengundang $\mathrm{KH}$. Baedlowi untuk memberikan ceramah, dan stasiun televisi menyiarkannya secara langsung hingga ceramah itu bisa dilihat dan didengar dari rumah ke rumah, hingga ke daerah-daerah, termasuk kota Jombang dan sekitarnya.

(Taufiqurrahman Al-Azizy, 2013: 58)

Dari kutipan di atas, yang menunjukkan ikon adalah 'televisi'. Gambar televisi menandai televisi. Secara heuristik televisi mempunyai makna pesawat penerima gambar siaran televisi. Secara hermeneutik mempunyai makna Kiai Baedlowi sudah sangat dikenal oleh seluruh masyarakat tidak hanya di kota Cirebon dan Jombang saja melainkan seluruh nusantara karena kepandaiannya dalam ilmu agama. la bukan hanya diminta untuk ceramah di masjid-masjid atau di pondok, tetapi juga melalui siaran televisi.

Di sofa yang panjang berwarna cokelat, abahnya sudah siap menunggunya. Kiai Baedlowi hendak mengujinya dengan berbagai soal agama. Tentang tauhid dan akidah. Tentang fiqih. Tentang muamalah. Asma menyadarinya, sebab begitulah kebiasaan abahnya.

(Taufiqurrahman Al-Azizy, 2013: 82)

Dari kutipan di atas, yang menunjukkan ikon adalah 'sofa'. Gambar sofa menandai sofa. Secara heuristik sofa mempunyai makna kursi panjang. Secara hermeneutik mempunyai makna sebuah kursi keluarga yang digunakan tempat duduk di ruangan tamu untuk membicarakan hal yang sangat resmi oleh Kiai Baedlowi dan Asma. Pembicaraan tersebut tentang ilmu-ilmu tauhid, akidah, dan fiqih.

Di matanya, Asma seperti burung kecil yang tengah belajar berkicau. Di bola matanya, masih tergambar azam yang kuat untuk menambah dan memperdalam ilmu-ilmu agamanya.

(Taufiqurrahman Al-Azizy, 2013: 83)

Dari kutipan di atas, yang menunjukkan ikon adalah 'bola mata'. Gambar bola mata menandai bola mata. Secara heuristik bola mata mempunyai makna bagian mata yang menyerupai bola dan dapat bergerak-gerak. Secara hermeneutik mempunyai makna Asma mempunyai sebuah bola mata yang indah dan dapat menarik simpati setiap orang yang melihatnya.

\section{Indeks}

Indeks adalah tanda yang mengandung hubungan kausal dengan apa yang ditandakan. Kutipan novel 3 Wali 1 Bidadari karya Taufiqurrahman Al-Azizy yang menunjukkan adanya indeks terdapat pada kutipan-kutipan berikut.

Dari tengah kota para wali, di sebuah bulan yang penuh dengan berkah, kisah ini dimulai. Ketika itu, Cirebon masih bersahabat. Lengkung cakrawala masih indah dipandang mata. Angin pantai yang panas menjadi sendu ketika memeluk pohon-pohon dan mengipasi dedaunan.

(Taufiqurrahman Al-Azizy, 2013: 25) 
Dari kutipan di atas, 'angin pantai yang panas' secara heuristik menandakan waktu pada siang hari di pantai. Sedangkan secara hermeneutik menandakan bahwa kota Cirebon terasa sejuk dan indah, dan bersih penghuninya. Hawa laut yang bertiup pun menjadikan sejuk setelah sampai di kota Cirebon.

Suara azan dari Masjid Kesepuhan tak hanya enak didengar telinga, tetapi membawa kedamaian dan rasa yang agung di dalam hati.

(Taufiqurrahman Al-Azizy, 2013: 25)

Dari kutipan di atas, 'suara azan dari Masjid Kesepuhan' secara heuristik menandakan waktu shalat telah tiba di Masjid Kesepuhan. Sedangkan secara hermeneutik menandakan suara azan dari Masjid Kesepuhan selalu membawa kedamaian karena yang mengumandangkan azan adalah orang yang sangat taat kepada Allah sehingga akan menimbulkan getaran jiwa kepada siapa saja yang mendengarnya.

Ketika itu, hiduplah sepasang suami-istri yang saling cinta dan penuh kasih. Rumahnya terletak di tengah-tengah kota, tak jauh dari Masjid Sang Cipta Rasa, alun-alun, dan Keraton Kasepuhan itu. Para orang tua yang masih memiliki ikatan batin dengan masa lalu menyakini bahwa di tubuh pasangan suami istri itu mengalir darah biru. Orang tua mereka masing-masing memilki pertalian darah yang kuat dengan keluhuran di masa lalu. Karena darah itu, orang-orang sekarang pun menghormati mereka. Orang-orang memanggil suami dan istri itu sebagai Kiai Baedlowi dan istri darinya sebagai Nyai Syarifah.

(Taufiqurrahman Al-Azizy, 2013: 25-26)

Dari kutipan di atas, 'orang-orang memanggil suami dan istri itu sebagai Kiai Baedlowi dan istri darinya sebagai Nyai Syarifah' secara heuristik menandakan mereka sebagai tokoh agama atau ulama besar ditempat tinggalnya. Sedangkan secara hermeneutik menandakan nama Kiai Baedlowi dan Nyai Syarifah sebuah nama yang penuh arti di tempat tinggalnya. Nama Kiai dan Nyai bukan hanya sekedar nama yang melekat pada diri mereka. Namun, nama mereka melambangkan keagungan hamba Allah yang begitu taat.

Para istri, para pemudi, dan anak-anak begitu menyayangi Nyai Syarifah, selain karena wajahnya yang kecemerlangannya menundukkan matahari dan kecemerlangan hatinya lebih terang dari mentari siang. Tutur katanya lembut.

(Taufiqurrahman Al-Azizy, 2013: 28)

Dari kutipan di atas, selain karena wajahnya yang kecemerlangannya menundukkan matahari dan kecemerlangan hatinya lebih terang dari mentari siang' secara heuristik menandakan bahwa Nyai Syarifah sangat cantik, putih, bersih, dan akhlaknya sangat baik. Sedangkan secara hermeneutik menandakan Nyai Syarifah tidak hanya cantik rupanya saja, tetapi juga cantik hatinya. la selalu berbuat baik kepada siapa saja. Dalam berpakaiannya pun selalu menutup aurat, menunjukkan bahwa ia wanita yang shaleha. Siapa pun yang melihatnya akan merasa iri karena ketaatannya kepada Allah.

Hal yang sama juga ditunjukkan orang-orang pada Kiai Baedlowi. Wajahnya bersih. Cahaya yang memancar dari wajah itu adalah bukti ketundukannya pada Allah Yang Terkasih. la seperti yang dikatakan para alim: selalu menjaga wudhu. Sinar terang yang memancar di bola matanya adalah bukti wudhu yang dijaganya sedang pancaran wajahnya yang agung adalah bukti wudhu itu telah masuk ke relung-relung jiwanya.

(Taufiqurrahman Al-Azizy, 2013: 29)

Dari kutipan di atas, 'cahaya yang memancar dari wajah itu adalah bukti ketundukannya pada Allah Yang Terkasih. la seperti yang dikatakan para alim: selalu menjaga wudhu. Sinar terang yang memancar di bola matanya adalah bukti wudhu yang dijaganya sedang pancaran wajahnya yang agung adalah bukti wudhu itu telah masuk ke relung-relung jiwanya' secara heuristik menandakan bahwa Kiai Baedlowi sangat taat beribadahnya. Dia pun tidak pernah meninggalkan shalat lima 
waktunya. Sedangkan secara hermeneutik menandakan bahwa ketaatan kepada Allah sudah menyatu dalam jiwa seorang Kiai Baedlow karena apa pun yang ia lakukan hanya semata-mata karena Allah. Sinar ketaatan itulah yang terpancar dari dalam jiwanya sehingga membuat orang kagum dan segan melihatnya.

Di malam hari, ia akan mengajak istrinya untuk bangun di sepertiga malam yang terakhir. Ketika ia rebah, menunduk, dan pasrah di hadapan-Nya, deras air matanya melebihi derasnya air mata hujan. Sedu sedan tangisnya seakan-akan mengalahkan tangis seorang ibu yang kehilangan anak terkasih.

(Taufiqurrahman Al-Azizy, 2013: 30)

Dari kutipan di atas, secara heuristik menandakan setiap tengah malam hari Kiai Baedlowi dan Nyai Syarifah selalu berdoa kepada Allah meminta ampun atas segala dosa-dosanya sampai air matanya keluar. Secara hermeneutik hal ini menandakan bahwa Kiai Baedlowi seorang hamba yang sangat tawaddu dan takut kepada Allah. Sehingga ia selalu merasa dirinya sebagai manusia yang lemah banyak melakukan kesalahan.

Wajah Bawuk tiba-tiba berubah pucat. Dirasakannya sorot mata orang itu begitu tajam menusuk hatinya, seakan tusukan itu mengeluarkan seluruh keburukan yang pernah ia lakukan selama ini, seumpama mengaduk-aduk dosa dan menumpahkan dari mulutnya. Senyum Kiai Baedlowi semakin lama semakin membuat wajahnya pucat pasi.

(Taufiqurrahman Al-Azizy, 2013: 34)

Dari kutipan di atas, secara heuristik menandakan bahwa Bawuk sangat ketakutan sekali kepada Kiai Baedlowi. Adapun secara hermeneutik menandakan sosok wajah Kiai Baedlowi mampu membuat Bawuk tersentuh hatinya dan merasa bersalah atas segala perbuatan yang selama ini ia lakukan kepada orang lain.

Bawuk pun berdiri dengan kaki yang semakin gemetaran. Wajahnya semakin pucat. Dirasakannya tibatiba seluruh persendiannya lunglai. Sebuah beban yang sangat kuat seakan menimpuk kepalanya dan menjungkalkan hatinya. Terbayang di pelupuk matanya air mata ibunya yang mengucur deras, memedihkan perbuatannya yang suka mencopet dan mabuk-mabukan. Terbayang pula tubuh lunglai dan ringkih ayahnya yang tergeletak sakit selama berbulan-bulan di atas balai-balai bambunya. Tak terasa, air mata Bawuk meluncur pelan. Kepedihan membuka selubung jiwanya. Dan dengan suara yang serak dan hampir lemah, ia memanggil lelaki yang tadi mengajaknya berbicara, "Pak Baedlowi .....! Pak Baedlowi ....!"

(Taufiqurrahman Al-Azizy, 2013: 35)

Dari kutipan di atas, secara heuristik menandakan Bawuk sangat menyesali perbuatannya yang suka mencopet dan mabuk-mabukan. Sedangkan secara hermeneutik menandakan semua perbuatan yang dilakukan Bawuk kepada orang lain yang sangat hina dimata Allah langsung menyentuh hatinya saat ia mencopet barang Kiai Baedloewi. Dari situlah, Bawuk tersadarkan akan kesalahannya pada orang lain dan langsung teringat oleh sosok ibunya yang selalu ia sakiti. Air mata baginya belum bisa menghampus dosa-dosanya.

\section{Simbol}

Simbol adalah tanda yang memiliki hubungan makna dengan yang ditandakan arbitrer, sesuai dengan konvensi suatu lingkungan sosial tertentu. Kutipan novel 3 Wali 1 Bidadari karya Taufiqurrahman Al-Azizy yang menunjukkan simbol terdapat pada kutipan-kutipan berikut.

Ketika itu, hiduplah sepasang suami-istri yang saling cinta dan penuh kasih. Rumahnya terletak di tengah-tengah kota, tak jauh dari Masjid Sang Cipta Rasa, alun-alun, dan Keraton Kesepuhan itu. Para orang tua yang masih memiliki ikatan batin dengan masa lalu menyakini bahwa di tubuh pasangan suami istri itu mengalir darah biru. Orang tua mereka masing-masing memiliki pertalian darah yang kuat dengan keluhan di masa lalu. Karena darah itu, orang-orang sekarang pun menghormati mereka. Orang-orang memanggil suami dari istri itu sebagai Kiai Baedlowi dan istri Nyai Syarifah. 
Dari kutipan di atas, secara heuristik 'suami istri' sebagai simbol orang yang sudah menikah secara sah secara agama dan hukum serta mempunyai sebuah keluarga. Sedangkan secara hermeneutik simbol 'suami istri' yang dimaksudkan adalah Kiai Baedlowi dan Nyai Syarifah.

Ketika itu, hiduplah sepasang suami-istri yang saling cinta dan penuh kasih. Rumahnya terletak di tengah-tengah kota, tak jauh dari Masjid Sang Cipta Rasa, alun-alun, dan Keraton Kasepuhan itu. Para orang tua yang masih memiliki ikatan batin dengan masa lalu menyakini bahwa di tubuh pasangan suami istri itu mengalir darah biru. Orang tua mereka masing-masing memilki pertalian darah yang kuat dengan keluhuran di masa lalu. Karena darah itu, orang-orang sekarang pun menghormati mereka. Orang-orang memanggil suami dari istri itu sebagai Kiai Baedlowi dan istri darinya Nyai Syarifah.

(Taufiqurrahman Al-Azizy, 2013: 25-26)

Dari kutipan di atas, secara heuristik 'darah biru' sebagai simbol keturunan bangsawan (ningrat) yang mempunyai ilmu yang tinggi. Sedangkan secara hermeneutik simbol 'darah biru' yang dimaksudkan adalah Kiai Baedlowi dan Nyai Syarifah.

Memang, tak kurang-kurang Kiai Baedlowi dan Nyai Syarifah mendatangi para tabib. Tabib-tabib itu telah menganjurkan berbagai macam ramuan dan obat, tetapi nyatanya tak berhasil.

(Taufiqurrahman Al-Azizy, 2013: 44)

Dari kutipan di atas, secara heuristik 'tabib' sebagai simbol orang yang pekerjaanya mengobati orang sakit secara tradisional. Sedangkan secara hermeneutik simbol 'tabib' yang dimaksudkan adalah tabib yang dimintain pertolongan oleh Kiai Baedlowi dan Nyai Syarifah agar membantu mereka mendapatkan seorang keturunan.

Nyai Syarifah juga telah meminum berbagai obat herbal yang bisa merangsang kehamilan. Para dokter pun sudah mereka datangi untuk berkonsultasi.

(Taufiqurrahman Al-Azizy, 2013: 44)

Dari kutipan di atas, secara heuristik 'dokter' sebagai simbol orang yang ahli dalam hal penyakit dan pengobatan. Sedangkan secara hermeneutik simbol 'dokter' yang dimaksudkan adalah orangorang yang berpengalaman dalam dunia kesehatan dan Nyai Syarifah pun mengakui bahwa keberadaan seorang dokter dapat membantu peramasalan mereka yang belum bisa mempunyai seorang anak.

Ketika sudah merasa cukup umur untuk masuk ke sekolah, Kiai Baedlowi dan Nyai Syarifah mengirim Asma ke sekolah yang terdekat. Ketika di rumah, mereka mengajarkan berbagai hal dan bermacam ilmu kepada si putri.

(Taufiqurrahman Al-Azizy, 2013: 48)

Dari kutipan di atas, secara heuristik 'putri' simbol sebagai panggilan untuk anak perempuan dari kalangan keluarga yang terhormat. Sedangkan secara hermeneutik simbol 'putri' yang dimaksudkan adalah Asma Putri Fadhilah.

"Dia masih terlalu kecil, Abah, bila dikirim ke Jawa Timur. Umi keberatan dengan keinginan Abah," kata Nyai Syarifah. "Selain itu, Jawa Timur memang tidak asing bagi Abah, tetapi sangat asing bagiku. Bagaimana aku bisa menahan kerinduan pada Asma bila jarak terbentang begitu jauh sedang kita tak mungkin setiap waktu bisa menjenguknya ke sana?"

(Taufiqurrahman Al-Azizy, 2013: 50)

Dari kutipan di atas, secara heuristik 'Umi' sebagai simbol ibu yang sangat beriman dan panggilan untuk keluarga dari seorang yang agamanya sangat tinggi dan 'Abah' sebagai simbol ayah. yang sangat beriman dan bertanggung jawab dalam keluarganya. Sedangkan secara hermeneutik simbol 'Umi' yang dimaksudkan adalah Nyai Syarifah. Sedangkan simbol 'Abah' yang dimaksudkan adalah 


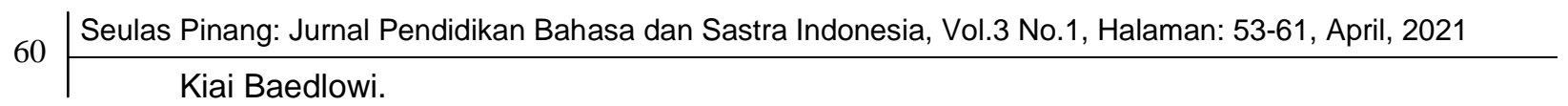

Maka, tibalah hari perpisahan itu. Asma mendekap erat uminya, seakan ia berat ditinggal sang umi. Nyai Syarifah pun tak kuasa membendung air matanya. Hatinya juga amatlah berat melepas putri tunggalnya itu.

(Taufiqurrahman al-Azizy, 2013: 51)

Dari kutipan di atas, secara heuristik 'putri tunggal' sebagai simbol anak perempuan satu-satunya. Secara hermeneutik simbol 'putri tunggal' yang dimaksudkan adalah Asma anak satu-satunya perempuan dari Kiai Baedlowi dan Nyai Syarifah yang sangat disayangi dan cintai.

la sangat disayangi teman-temannya sesama santri, juga sering kali menjadi buah bibir kebanggaan Kiai dan Nyai Nahnuddin di pesantren ini.

(Taufiqurrahman al-Azizy, 2013: 55)

Dari kutipan di atas, secara heuristik 'buah bibir' sebagai simbol bahan pembicaraan orang. Sedangkan secara hermeneutik simbol 'buah bibir' yang dimaksudkan adalah Asma menjadi bahan pembicaraan di pesantren dalam hal yang positif oleh teman-temannya dan gurunya karena kepandaiannya.

Asma tak hanya belajar dan memperdalam ilmu-ilmu agama. Di Jombang yang indah ini, ia pun belajar ilmu-ilmu dunia. Bahkan, tak hanya ilmu-ilmu yang dipelajarinya. la belajar ilmu kehidupan dari temantemannya sesama santri.

(Taufiqurrahman Al-Azizy, 2013: 59)

Dari kutipan di atas, secara heuristik 'santri'sebagai simbol orang-orang yang belajar mendalami ilmu agama. Sedangkan secara hermeneutik simbol 'santri' yang dimaksudkan adalah teman-teman santri dari Asma yang satu pesantren.

Kedua, mereka bermaksud hendak menjodohkan putra tunggalnya kepada putri sang kiai. Mereka adalah orang besar dengan segala kebesaran dan kemulian jiwanya. K.H. Najmudin adalah seorang pengasuh pesantren besar di wilayah Tasikmalaya.

(Taufiqurrahman Al-Azizy, 2013: 64)

Dari kutipan di atas, secara heuristik 'putra tunggal' sebagai simbol anak laki-laki satunya. Sedangkan secara hermeneutik simbol 'anak tunggal' yang dimaksudkan adalah anak laki-laki satunya $\mathrm{KH}$. Najmudin akan dijodohkan oleh putri Kiai Baedlowi.

"Sambil menunggu waktu itu," Kiai Baedlowi melanjutkan, "alangkah bahagianya bila putramu sudi datang ke gubukku ini.

(Taufiqurrahman Al-Azizy, 2013: 68)

Dari kutipan di atas, secara heuristik 'gubuk' sebagai simbol rumah. Simbol 'gubuk' yang dimaksudkan adalah rumah Kiai Baedlowi. Menandakan Kiai Baedlowi walaupun dia orang kaya tetapi sangat rendah diri dan tidak sombong.

Kiai Baedlowi tersentak mendengar munajat Asma. Begitu halnya dengan Nyai Syarifah.

(Taufiqurrahman Al-Azizy, 2013: 87)

Dari kutipan di atas, secara heuristik 'munajat' sebagai simbol doa. Secara hermeneutik simbol 'munajat' yang dimaksudkan adalah doa yang diucapkan oleh Asma dan Nyai Syarifah kepada Allah.

Oh, Umi..., mungkin sudah saatnya bagiku untuk bertemu dengan para alim. Hatiku tak sanggup memahami Asma, mudah-mudahan hati para alim sanggup memahaminya hingga tenanglah jiwa kita.

(Taufiqurrahman Al-Azizy, 2013: 104) 
SEMIOTIK DALAM NOVEL 3 WALI 1 ... $\mid 61$

Dari kutipan di atas, secara heuristik 'para alim' sebagai simbol orang-orang yang berilmu dalam agama Islam. Sedangkan secara hermeneutik simbol 'para alim' yang dimaksudkan adalah orang yang berilmu dalam agama Islam yang bisa memahami tentang kejiwaannya Asma.

Ada beberapa ulama yang hendak dituju oleh Kiai Baedlowi. Jumlahnya lima. Tiga ulama tinggal di kota lain. Dua ulama tinggal di kota lain. Dua ulama tinggal di kota wali ini.

(Taufiqurrahman al-Azizy, 2013: 105)

Dari kutipan di atas, secara heuristik 'ulama' sebagai simbol orang yang ahli dalam hal pengetahuan agama Islam. Sedangkan secara hermeneutik simbol 'ulama' yang dimaksudkan adalah para ulama yang berada di kota Cirebon dan di luar kota Cirebon yang akan dikunjungi oleh Kiai Baedlowi.

\section{PENUTUP}

Seperti pada novel ini yang penulis analisis 'gambar pohon menandai pohon, gambar rumah menandai rumah, dan lain sebagainya. Indeks tersebut pada novel ini dipakai untuk memahami perwatakan tokoh utama yaitu Asma Putri Fadhila dan tokoh tambahan yaitu Kiai Baedlowi, Nyai Syarifah, Ghozali, Bilal, Arsyad, Yusrina, dan tokoh-tokoh tambahan lainnya. Misalnya pada tokoh utama yaitu Asma yang menyatakan bahwa dia tokoh yang sangat cantik seperti Bidadari dan pandai dalam ilmu agama dan ilmu dunia. Simbol-simbol pada novel ini ditemukan pada unsur intrinsik yaitu penokohan, amanat, gaya bahasa, dan tema. Misalnya pada unsur intrinsik penokohan yang bisa diketahui oleh penulis adalah simbol 'darah biru'. Simbol 'darah biru' yang dimaksudkan adalah tokoh Kiai Baedlowi dan Nyai Syarifah.

Semiotik atau tanda yang ditemukan pada novel 3 Wali 1 Bidadari karya Taufiqurrahman Al-Azizy yang meliputi ikon, indeks, dan simbol melalui unsur intrinsik yaitu tema, penokohan, latar, gaya bahasa, dan amanat. Novel 3 Wali 1 Bidadari karya Taufiqurrahman Al-Azizy sebuah novel Islami yang banyak sekali tanda-tandanya yang secara tersirat, sehingga dapat penulis artikan melalui jenis tanda ikon, indeks, dan simbol menurut teori C.S. Pierce.

Tanda ikon, indeks, dan simbol peranannya dalam novel ini sangat menggambarkan dan memperjelas sebuah ceritanya. Hal tersebut dapat menambah pengetahuan pembaca tentang agama Islam. Sehingga mempunyai makna yang sangat jelas dan berarti dengan adanya tanda 'ikon, indeks, dan simbol' yang dapat diartikan maknanya oleh pembaca.

\section{DAFTAR PUSTAKA}

Arikunto, Suharsimi. 2010. Penelitian Tindak Kelas. Jakarta: Bumi Aksara.

Depdiknas. (2012). Kamus Besar Bahasa Indonesia Edisi Keempat. Jakarta: PT Gramedia Pustaka.

Endraswara, Suwardi. 2010. Metodologi Penelitian Sastra. Yogyakarta: Niaga Swadaya.

Ratna, Nyoman Kutha. 2010. Teori, Metode, dan Teknik Penelitian Sastra. Yogyakarta: Pustaka Belajar.

Rokmansyah, Alfian. 2014. Studi dan Pengkajian Sastra. Yogyakarta: Graha Ilmu.

Semi, M. Atar. 2011. Anatomi Sastra. Padang: Angkasa Raya.

Sudjiman, Panuti. 2010. Memahami Cerita Rekaan. Yogyakarta: Pustaka Jaya.

Tarigan, H.G. 2011. Prinsip-Prinsip Dasar Sastra. Bandung: Angkasa.

Wellek, Rene dan Austin Warren. 2010. Teori Kesusasteraan. Jakarta: PT Gramedia Pustaka. 